\title{
BELAS KASIH DIRI PADA NARAPIDANA KASUS TERORISME YANG MENJALANI PROGRAM DERADIKALISASI
}

\author{
Achmad Mauluddin Alfithon \& Muhammad Syafiq \\ Program Studi Psikologi, Universitas Negeri Surabaya, Jln. Lidah Wetan, Surabaya 60213, Indonesia
}

Korespondensi: muhammadsyafiq@unesa.ac.id

\section{SELF-COMPASSION OF TERRORIST PRISONERS UNDERGOING DERADICALIZATION PROGRAM}

\begin{abstract}
This study aims to explore the self-compassion of terrorist prisoners. Three terrorist inmates from Porong Correctional Facility located in Surabaya, Indonesia, were recruited after completing deradicalization program as referred by the correction officers. Data were obtained using semi-structured interviews and were analyzed using thematic analysis strategies. The concept of self-compassion as proposed by Neff (2003) was used as a theoretical framework in the analysis. The study found that respondents reported thoughts, feelings, and actions that demonstrated their self-compassion, which was likely to be attributable to their participation in deradicalization program. Positive inducements from the correctional facility officers, as a part of the deradicalization program, seemed to offer a new perspective. In particular, their belief in God's forgiveness and the perceived social support from the facility assisted them to perceive themselves in a less self-blaming attitude. Participants' contemplation of human being as imperfect also enabled them to accept their transgression and develop empathy towards others. The finding suggests that selfcompassion could be a good indicator of the effectiveness of deradicalization program among terrorist prisoners.
\end{abstract}

Manuscript type: Original Research

\section{Article history:}

Received 16 October 2020

Received in revised form 14 March 2021

Accepted 15 April 2021

Available online 1 June 2021

\section{Keywords:}

deradicalization

self-compassion

terrorist prisoners

\begin{abstract}
Abstrak
Penelitian ini bertujuan untuk mengeksplorasi belas kasih diri pada narapidana terorisme. Tiga responden dipilih dan direkrut dari lembaga pemasyarakatan Kelas I Surabaya (Porong) Indonesia dengan bantuan staf penjara berdasarkan partisipasi dalam program deradikalisasi. Data dikumpulkan menggunakan wawancara semi-terstruktur dan dianalisis dengan analisis tematik menggunakan konsep belas kasih diri dari Neff (2003). Hasil penelitian menunjukkan bahwa ketiga responden melaporkan pikiran, perasaan, dan tindakan yang mengindikasikan belas kasih diri yang dapat terjadi sebagai bagian dari hasil partisipasi dalam program deradikalisasi. Perlakuan positif petugas, yang merupakan bagian dari program deradikalisasi, diyakini telah membuka pikiran para responden. Secara khusus, keyakinan mereka atas ampunan Tuhan dan dukungan sosial petugas penjara telah membantu mereka untuk terhindar dari sikap menyalahkan diri sendiri secara berlebihan. Kesadaran bahwa tidak ada manusia yang sempurna membuat responden dapat menerima kesalahannya di masa lalu dan memupuk rasa empati pada orang lain. Temuan penelitian ini mengindikasikan bahwa belas kasih diri dapat digunakan sebagai indikator psikologis dari efektivitas proses deradikalisasi narapidana terorisme.
\end{abstract}

Kata Kunci: belas kasih diri, deradikalisasi, narapidana terorisme

\section{Dampak dan Implikasi dalam Konteks Ulayat}

Terorisme merupakan masalah sosial yang serius di Indonesia. Salah satu pendekatan untuk mengatasinya ialah melalui program deradikalisasi. Penelitian ini memberikan wawasan mengenai peran belas kasih diri sebagai indikator dalam mengevaluasi keberhasilan program deradikalisasi pada narapidana terorisme di Lapas Porong Surabaya. Para responden telah menjalani program deradikalisasi oleh BNPT sejak masa penahanan dan oleh Lapas ketika menjalani hukuman penjara. Hasil penelitian menunjukkan bahwa program deradikalisasi yang menekankan pada pendekatan interpersonal humanis telah memfasilitasi para responden untuk meninggalkan ideologi dan kelompok terorisme. Hasil penelitian ini menggambarkan karakteristik belas kasih diri yang konsisten dengan teori Neff (2003), serta ditampilkan secara khas pada narapidana terorisme dalam konteks Indonesia. 


\section{PENDAHULUAN}

Terorisme masih menjadi masalah krusial yang dihadapi banyak negara di dunia, termasuk Indonesia. Indeks Terorisme Global tahun 2020 menempatkan Indonesia sebagai negara paling terdampak terorisme dengan peringkat empat di Asia Pasifik dan peringkat ke-37 secara global (Institute of Economics and Peace [IEP], 2020). Aksi terorisme di Indonesia mulai mendapatkan sorotan ketika terjadi serangan Bom Bali I tahun 2002 yang menewaskan 202 orang (Britannica, 2020). Serangan terorisme terus berlangsung sejak tragedi tersebut hingga saat ini dalam skala yang lebih kecil dengan pelaku perorangan maupun kelompok.

Upaya pencegahan terorisme, penindakan para pelaku teror, serta pembinaan para tahanan dan narapidana kasus terorisme telah dilakukan pemerintah melalui Badan Nasional Pemberantasan Terorisme (BNPT) bersama lembaga pemerintah lainnya. Upaya mengatasi terorisme dilakukan melalui pendekatan keras maupun lunak (Yanuarti \& Sularto, 2014). Pendekatan keras dilakukan melalui perburuan, penangkapan, dan penegakan hukum secara tegas. Sementara itu, pendekatan lunak dilakukan melalui program deradikalisasi. Deradikalisasi adalah upaya untuk mengubah pemikiran dan keyakinan anggota kelompok teroris agar menolak ideologi terorisme yang semula mereka anut dengan beragam cara, mulai dari kontra ideologi hingga pendekatan psikologis dan sosial ekonomi (Horgan \& Altier, 2012; Hwang, 2018). Secara global, hasil penelitian menunjukkan bahwa pendekatan keras tidak cukup berhasil dalam melawan ekstremisme kekerasan dan bahwa perlakuan positif lebih efektif dibandingkan penegakan secara keras dalam menjalankan kebijakan kontra terorisme (Kundnani \& Hayes, 2018; Schmid, 2013). Pendekatan ramah melalui program deradikalisasi lebih menjanjikan karena dapat meningkatkan kualitas hidup para pelaku, mantan pelaku, bahkan mereka yang rentan terlibat dalam terorisme (Putra \& Sukabdi, 2014).

Kajian atas deradikalisasi para pelaku terorisme dan kriteria keberhasilannya masih terus menjadi fokus penelitian hingga saat ini (Cherney, 2018; Horgan \& Braddock, 2010; Hwang, 2018), terutama penelitian yang dapat mengungkap data primer dari mereka yang berhasil menjalani proses deradikalisasi (Cherney, 2016; Hettiarachchi, 2018).

\section{Program Deradikalisasi di Indonesia}

Desain deradikalisasi di Indonesia terdiri dari tiga strategi utama, yaitu reedukasi, rehabilitasi, dan resosialisasi-reintegrasi (Institute for Policy Analysis of Conflict [IPAC], 2016; Yanuarti \& Sularto, 2014). Strategi reedukasi dijalankan melalui upaya pencerahan dan koreksi atas 
doktrin-doktrin radikal kekerasan dengan melibatkan ahli agama dari perguruan tinggi dan diskusi personal dengan para mantan pimpinan jaringan terorisme yang telah menolak ideologi terorisme. Program rehabilitasi dilaksanakan melalui pembinaan di lembaga pemasyarakatan (lapas) yang bekerja sama dengan BNPT, meliputi pembinaan mental yang melibatkan pelatihan manajemen konflik dan pengelolaan emosi dengan bantuan ahli psikologi dan pihak eksternal lain, serta pelatihan vokasional dan pemberian hak aktivitas ekonomi oleh lapas. Rehabilitasi dalam bentuk pemberdayaan ekonomi dan bantuan pendidikan anak juga diberikan pada keluarga narapidana terorisme. Sementara itu, strategi resosialisasi-reintegrasi dijalankan oleh lapas bekerja sama dengan BNPT dan melibatkan lembaga publik, seperti lembaga swadaya masyarakat (LSM), para pejabat kepolisian, dan komunitas para mantan narapidana terorisme yang telah kembali hidup normal di masyarakat untuk mengadakan kegiatan di dalam lapas, baik secara formal, seperti: lokakarya, pelatihan, atau seminar, maupun kegiatan informal, seperti silaturahmi. Pada narapidana terorisme yang akan bebas, program resosialisasi dan reintegrasi ini dilakukan bersama dengan pimpinan informal maupun formal, seperti ketua RT/RW, kelurahan, Kepolisian Sektor (Polsek), maupun Komando Distrik Militer (Kodim) tempat tinggal narapidana terorisme ketika nanti akan bebas.

Program deradikalisasi di Indonesia berlangsung selama para pelaku terorisme ditahan dan akhirnya dihukum di lapas, serta setelah bebas dari penjara. Hingga tahun 2020, dilaporkan terdapat 524 narapidana teroris yang ditempatkan tersebar di 88 lapas di seluruh Indonesia (Badan Pembinaan Hukum Nasional, 2020). Narapidana kasus terorisme termasuk dalam kategori narapidana berisiko tinggi, sehingga mendapatkan perlakuan khusus dan dibedakan dengan narapidana umum (Mareta, 2018). Perlakuan khusus yang didapatkan oleh narapidana kasus terorisme adalah pemisahan blok atau sel tahanan dengan narapidana umum, serta mendapatkan program deradikalisasi yang dilaksanakan oleh BNPT bekerja sama dengan lapas tempat narapidana terorisme menjalani hukuman. Partisipasi narapidana terorisme dalam program deradikalisasi ini, terutama reedukasi dan rehabilitasi, tidak dipaksa karena kesukarelaan mereka menjadi faktor penting efektivitas program.

\section{Deradikalisasi dan Belas Kasih Diri}

Kriteria utama keberhasilan program deradikalisasi di lapas adalah narapidana terorisme bersedia untuk bersumpah dan menandatangani ikrar kesetiaan pada Negara Kesatuan Republik Indonesia (NKRI), mengakui kesalahan di masa lalu, dan tidak lagi setuju dengan ideologi 
terorisme yang mereka yakini sebelumnya (Mareta, 2018). Sukabdi (2015) menyatakan bahwa indikator untuk melihat keberhasilan program deradikalisasi adalah munculnya perilaku positif terhadap orang lain dan sikap penolakan terhadap kekerasan. Narapidana terorisme yang sudah sadar dan menolak ideologi terorisme akan mengakui kesalahan di masa lalu, mampu mengkritisi diri sendiri dan menjadi pribadi yang lebih baik, mampu berintegrasi di masyarakat, memiliki keterampilan hidup, seperti wirausaha dan kemampuan vokasional lainnya, serta mampu menerima kearifan lokal. Berdasarkan berbagai kriteria tersebut, selain ikrar kesetiaan pada negara, dapat dilihat bahwa narapidana terorisme yang sudah sadar akan mengakui kesalahannya di masa lalu dan mengubah cara pandangnya terhadap diri sendiri dan orang lain di sekitarnya. Perubahan diri semacam ini memerlukan pemaafan atas kesalahan di masa lalu dan perubahan dalam prinsip hidup agar lebih bersikap manusiawi, serta memiliki hubungan sosial yang lebih adaptif dan harmonis dalam masyarakat yang beragam.

Atas dasar alasan tersebut, penting untuk menggunakan konsep psikologis yang relevan dalam rangka mengkaji perubahan diri pada para mantan narapidana terorisme yang telah terderadikalisasi. Salah satu konsep psikologis yang relevan adalah belas kasih diri (selfcompassion). Menurut Neff (2003), belas kasih diri adalah sikap terhadap diri sendiri yang hangat dan penuh pengertian ketika menghadapi kesulitan hidup, tanpa menghakimi kekurangan dan kelemahan diri karena adanya kesadaran bahwa kelemahan diri dan membuat kesalahan merupakan bagian dari pengalaman manusia pada umumnya. Belas kasih diri membuat individu menjadi suportif secara emosional terhadap dirinya sendiri dan orang lain ketika menghadapi kesulitan dan ketidaksempurnaan dalam hidupnya (Yarnell \& Neff, 2012). Neff (2012) menjelaskan bahwa belas kasih diri melibatkan tiga komponen positif utama yang masing-masing berada dalam tegangan dengan faktor psikologis negatif, yaitu mengasihi diri vs. menghakimi diri (self-kindness vs. selfjudgement), kemanusiaan universal vs. isolasi (common humanity vs. isolation), dan mindfulness vs. overidentifikasi (overidentification). Ketiga komponen tersebut berkombinasi dan saling berinteraksi dalam menciptakan belas kasih diri (Dreisoerner dkk., 2020). Belas kasih diri membuat individu dapat menerima pengalaman negatif di masa lalu, meningkatkan rasa percaya pada orang lain, serta membuat individu merasa aman dalam menjalani kehidupan sosial mereka (Yarnell \& Neff, 2012).

Mengkaji belas kasih diri pada narapidana terorisme yang telah bertobat penting dilakukan mengingat kondisi khas yang mereka jalani. Kondisi khas tersebut berkaitan dengan evaluasi narapidana terorisme terhadap masa lalu mereka selama terlibat dalam jaringan terorisme dan 
kehidupan saat ini dalam menjalani masa hukuman di lapas. Di satu sisi, narapidana terorisme dituntut untuk menyesali perbuatannya dan mengakui kesalahannya di masa lalu. Di sisi lain, mereka tidak diarahkan untuk mengevaluasi diri mereka secara negatif. Program rehabilitasi sebagai bagian dari program deradikalisasi di lapas justru mendorong mereka untuk memandang diri mereka yang baru saat ini secara lebih positif agar mereka dapat hidup bersama masyarakat yang beragam secara harmonis, baik saat ini ketika dalam lapas maupun nanti pada saat mereka akan bebas (Mareta, 2018).

Penelitian belas kasih diri dalam konteks terorisme belum banyak dilakukan. Penelitian paling dekat dilakukan pada topik pelaku kriminal kekerasan. Penelitian-penelitian belas kasih diri dalam konteks kriminalitas umumnya menyimpulkan bahwa belas kasih diri pada pelaku dan mantan pelaku kriminal kekerasan dapat meningkatkan aspek positif mereka dalam hal ikatan sosial, empati, harga diri, dan kontrol diri, serta dapat menghalangi mereka untuk melakukan kekerasan, mencegah perilaku antisosial, menurunkan perilaku impulsif, dan penolakan terhadap tindak kriminal (Gómez dkk., 2020; Morley, 2015; Morley, 2018; Morley dkk., 2016). Penelitian lain menunjukkan bahwa belas kasih diri yang tinggi memiliki kaitan dengan penurunan perilaku melanggar norma atau etika karena dapat meningkatkan rasa terikat dengan nilai moralitas dalam kehidupan bersama orang lain (Yang dkk., 2020).

Menimbang hasil berbagai penelitian tersebut, diyakini bahwa belas kasih diri adalah topik yang tepat untuk dikaji pada narapidana terorisme yang pernah terlibat dalam ideologi dan aksi kekerasan terorisme, tetapi saat ini telah bertobat dan meninggalkan ideologi dan kelompok terorisme tersebut. Penelitian ini bertujuan untuk mengkaji belas kasih diri pada narapidana terorisme yang dinyatakan telah berhasil menjalani program deradikalisasi oleh petugas lapas. Indikator keberhasilannya adalah mereka telah menandatangi ikrar kesetiaan pada NKRI, pernyataan penyesalan atas keterlibatan aksi terorisme di masa lalu, menolak ideologi kekerasan, dan janji untuk tidak mengulangi lagi tindak kejahatan terorisme. Lapas Kelas 1 Surabaya (Lapas Porong) dipilih sebagai tempat penelitian karena merupakan lapas yang dinilai sukses dalam menjalankan program deradikalisasi. Sebagai contoh, empat narapidana terorisme binaan Lapas Porong menjadi pelopor pertama untuk ikrar setia NKRI pada tahun 2015 (Direktorat Jenderal Pemasyarakatan Kemenkumham RI, 2015). 


\section{Deradikalisasi di Lapas Porong}

Kebijakan program deradikalisasi narapidana teroris pada tiap lapas di Indonesia tidak sama mengingat kebutuhan dan kemampuan tiap lapas berbeda. Lapas Porong dinilai memiliki kebijakan deradikalisasi narapidana terorisme yang baik. Salah satu pembeda Lapas Porong dibanding lapas lain dalam implementasi program deradikalisasi adalah ditugaskannya secara resmi staf senior yang khusus mendampingi dan bertanggung jawab atas kondisi narapidana terorisme. Petugas khusus ini bertugas untuk melakukan pendekatan personal yang baik pada narapidana terorisme dan menjadi penilai pada level pertama apakah narapidana masih radikal atau sudah moderat. Evaluasi petugas pendamping khusus ini menjadi pertimbangan dalam pengajuan remisi atau grasi, atau pembebasan bersyarat bagi narapidana terorisme.

Selain itu, di luar kegiatan yang umumnya diberikan pada narapidana umum, seperti kegiatan olah raga, latihan kerja, dan layanan spiritual, Lapas Porong juga memberikan perhatian khusus pada narapidana terorisme dengan menyediakan usaha ekonomis, seperti kesempatan berjualan makanan atau berkebun sayur untuk dijual. Sesuai kebijakan pemerintah, narapidana terorisme juga mendapatkan sel khusus tersendiri untuk membatasi pengaruh ide-ide radikal mereka terhadap narapidana umum.

Program deradikalisasi di Lapas Porong melibatkan kerja sama dengan pihak eksternal, terutama BNPT, untuk penilaian tingkat radikalisme dan moderasi, bantuan sosial ekonomi, serta kebijakan kelonggaran hak kunjungan keluarga. Pihak keamanan di kawasan sekitar, meliputi Polsek, Bintara Pembina Desa (Babinsa), dan Keamanan dan Ketertiban Masyarakat (Kamtibmas) juga berkunjung secara rutin, terutama untuk membangun kontak personal lebih dekat dengan narapidana terorisme demi menghilangkan sikap permusuhan mereka terhadap pihak keamanan. Pihak eksternal lain, yaitu lembaga sosial mantan teroris Yayasan Lingkar Perdamaian Lamongan, dilibatkan untuk memberikan dukungan emosional dan sosial pada narapidana terorisme melalui kunjungan rutin. LSM Yayasan Prasasti Perdamaian (YPP) Jakarta juga dilibatkan untuk memberikan beberapa pelatihan, seperti manajemen konflik dan komunikasi interpersonal, serta kerja sama dengan Aliansi Indonesia Damai (AIDA) Jakarta untuk mempertemukan narapidana mantan pelaku terorisme dengan para korban aksi terorisme dalam rangka meningkatkan sikap empati dan damai pada diri narapidana terorisme. Lapas Porong juga mengundang secara personal ahli agama dan mantan narapidana, serta ideolog terorisme yang telah insyaf untuk melakukan pendekatan personal dan dialog dengan narapidana terorisme untuk memperbaiki paham radikal mereka. 


\section{METODE}

\section{Partisipan}

Tiga narapidana kasus terorisme dipilih dari enam narapidana terorisme yang saat ini berada di Lapas Kelas I Porong Surabaya. Alasan pemilihan adalah kriteria keberhasilan deradikalisasi seperti yang dilaporkan oleh petugas penjara, yaitu telah menandatangani pernyataan menyesali aksi teror yang pernah dilakukan, menolak ideologi terorisme, dan ikrar kesetiaan terhadap NKRI. Profil dan latar belakang kasus dari ketiga responden dapat dilihat di Tabel 1.

Tabel 1.

Profil Responden Penelitian

\begin{tabular}{|c|c|c|c|c|}
\hline Inisial & $\begin{array}{c}\text { Jenis } \\
\text { Kelamin }\end{array}$ & Usia & Riwayat Kasus & Hukuman \\
\hline AJ & $\mathrm{L}$ & 46 tahun & $\begin{array}{l}\text { - Penyerangan markas Brimob di Pulau } \\
\text { Seram, Maluku } 2005 \text { (Konflik Ambon) } \\
\text { - Pelatihan militer di Moro Filipina } \\
\text { - Afiliasi: Komite Aksi Penanggulangan } \\
\text { Krisis (KOMPAK) }\end{array}$ & $\begin{array}{l}\text { Seumur hidup } \\
\text { Ikrar kesetiaan NKRI } 2015\end{array}$ \\
\hline $\mathrm{AL}$ & $\mathrm{L}$ & 52 tahun & $\begin{array}{l}\text { - Ledakan Bom Makassar } 2003 \\
\text { - Kepemilikan senjata ilegal } 2018 \\
\text { - Afiliasi: Darul Islam Sulawesi Selatan }\end{array}$ & $\begin{array}{l}5 \text { tahun } \\
3.5 \text { tahun } \\
\text { Ikrar kesetiaan NKRI } \\
\text { Maret } 2020\end{array}$ \\
\hline $\mathrm{H}$ & $\mathrm{L}$ & 54 tahun & $\begin{array}{l}\text { - Keterlibatan Bom Bali I } \\
\text { - Pelatihan militer di Afghanistan dan } \\
\text { Moro Filipina. } \\
\text { - Afiliasi: Jamaah Islamiyah } \\
\end{array}$ & $\begin{array}{l}20 \text { tahun } \\
\text { Ikrar kesetiaan NKRI } 2015\end{array}$ \\
\hline
\end{tabular}

Program deradikalisasi telah diterima oleh ketiga responden di atas dari BNPT sejak penangkapan dan penahanan mereka oleh Detasemen Khusus 88 (Densus 88) di Mako Brimob Kelapa Dua Depok hingga deradikalisasi yang dijalankan oleh Lapas Porong bekerja sama dengan BNPT dan lembaga lain ketika telah menjalani hukuman. Bentuk program deradikalisasi selama masa penangkapan dan penahanan yang diterima, meliputi perlakuan yang baik dan manusiawi dengan menghargai hak-hak pribadi, seperti kebutuhan pangan, sandang, dan menjalankan ibadah agama, serta bantuan modal dan biaya pendidikan bagi keluarga para tersangka terorisme yang kooperatif. Selama masa tahanan, para responden ini dikunjungi ahli psikologi untuk mengevaluasi kondisi psikologis dan tingkat radikalismenya, dikunjungi pakar agama berdialog terkait ideologi agamanya, serta dikunjungi mantan pimpinan dan ideolog kelompok terorisme yang telah bertobat untuk melakukan pendekatan personal dan penyadaran dari paham radikal. Setelah dipindah ke 
Lapas Porong, ketiga responden melanjutkan program deradikalisasi sesuai kebijakan Lapas Porong seperti yang telah diuraikan sebelumnya.

Dua staf lapas juga diwawancarai sebagai significant other (SO) untuk melengkapi dan mengkonfirmasi data dari para responden. SO1 adalah Kepala Seksi Bimbingan Kemasyarakatan yang telah menjadi staf khusus narapidana terorisme atau wali narapidana kasus terorisme (napiter) sejak tahun 2007 dan telah mendampingi ketiga responden penelitian ini sejak penugasannya, yaitu AJ dan H selama sekitar 13 tahun, serta AL selama sekitar 3 bulan. Sementara itu, SO2 adalah asisten wali napiter yang bertugas sejak tahun 2017 dan telah mendampingi responden AJ dan $\mathrm{H}$ selama sekitar 3 tahun, serta mendampingi responden AL selama 3 bulan lebih.

\section{Desain}

Penelitian ini menggunaan pendekatan kualitatif untuk mengkaji belas kasih diri pada narapidana terorisme yang sudah terderadikalisasi agar dapat memperoleh pemahaman yang detail, lengkap, dan mendalam terkait topik tersebut (Creswell, 2014). Metode yang digunakan adalah studi kasus karena penelitian ini berfokus untuk menggali belas kasih diri sebagai pengalaman unik yang dimiliki oleh individu dengan profil yang khusus (sebagai narapidana teroris) dalam konteks waktu dan tempat tertentu (Yin, 2014), yaitu sedang menjalani hukuman di penjara.

\section{Prosedur}

Data dikumpulkan menggunakan wawancara semiterstruktur yang dipandu berdasarkan pedoman umum yang merujuk pada konsep belas kasih diri dari Neff (2003), tetapi peneliti mengembangkan pertanyaan lebih lanjut untuk mendalami jawaban responden. Wawancara dilakukan masing-masing satu kali pada para responden dengan durasi 50-60 menit melalui telepon. Wawancara telepon dilakukan karena kebijakan pembatasan kunjungan dari Lapas Porong menyikapi pandemi COVID-19. Namun, sebelum kebijakan pembatasan, peneliti pertama dan kedua telah melakukan kunjungan langsung ke Lapas Porong untuk memperoleh data awal dari staf penjara terkait narapidana yang sukses menjalani deradikalisasi dan melakukan proses rekruitmen responden penelitian.

Seluruh responden penelitian ini telah diberikan informasi yang mencukupi dan telah memberikan persetujuan untuk terlibat dalam penelitian ini dengan menandatangani formulir persetujuan berpartisipasi (consent form). 


\section{Teknik Analisis}

Teknik analisis data yang digunakan adalah analisis tematik yang dilakukan dengan cara mengidentifikasi pola-pola tema dari data (Braun \& Clarke, 2006). Analisis data bersifat top-down karena mengacu pada konsep belas kasih diri (Neff, 2003). Pendekatan top-down ini dipilih agar peneliti dapat memahami karakteristik belas kasih diri pada responden narapidana terorisme secara lebih akurat. Peneliti menggunakan uji keabsahan triangulasi dengan melakukan validasi data responden penelitian dengan laporan dari staf lapas. Bias-bias dalam penelitian ini juga telah diupayakan untuk diatasi dengan cara peneliti pertama dan kedua saling mengklarifikasi dan mengevaluasi interpretasi yang dilakukan masing-masing.

\section{HASIL}

Temuan penelitian ini dikategorikan menjadi tiga tema utama merujuk pada konsep belas kasih diri Neff (2012), yaitu mengasihi diri (self-kindness), kemanusiaan universal (common humanity), dan mindfulness. Barnard dan Curry (2011) menyatakan bahwa ketiga komponen dari belas kasih diri ini tidak tersusun dalam tahapan, melainkan merupakan suatu kombinasi yang membuat belas kasih diri menjadi khas dan berbeda dengan topik tentang diri lainnya.

\section{Mengasihi Diri}

Para responden menunjukkan penyesalan dan mengakui kesalahan. Namun, rasa penyesalan dan bersalah tersebut dapat dikelola dengan baik, sehingga mereka dapat memaafkan diri sendiri dan menerima hidupnya saat ini. Hal ini menunjukkan para responden memiliki ciri mengasihi diri, yaitu menyikapi dirinya secara lebih positif dan terhindar dari rasa marah, frustasi, dan menghukum diri sendiri (self-judgement) akibat kesalahan di masa lalu.

Responden AJ pada mulanya pergi ke Ambon saat terjadi konflik sosial untuk misi kemanusiaan. Namun, karena terpapar pemahaman takfiri (keyakinan untuk membunuh atau memerangi individu Muslim lain yang memusuhi mereka sebagai kafir atau keluar dari Islam), akhirnya ia ikut terlibat dalam penyerangan markas polisi di Pulau Seram hingga menyebabkan jatuhnya korban. Ia menyesali keterlibatannya dalam aksi tersebut.

Jadi penyesalan karena memiliki pemahaman takfiri dan menghalalkan darah orang kafir, sehingga lebih mudah melakukan kekerasan atas nama takfiri tersebut dan berujung diamankan aparat serta menimbulkan korban. (AJ) 
AJ menyadari bahwa penyebab dari kesalahannya dahulu adalah karena kurangnya pengetahuan agama yang ia miliki. Staf penjara (SO1) memberikan konfirmasi sebagai berikut.

Dia menyesal karena menimbulkan korban jiwa yang seharusnya tidak terjadi. Jadi saya bacakan sedikit grasinya ya: "Saya akui itu adalah kesalahan saya akibat kebodohan kami akibat menelan satu informasi dari satu arah saja tanpa mencoba mencari pemahaman dari pintu yang lain sehingga kami mudah terprovrokasi”. (SO1)

Responden AL juga melaporkan rasa penyesalannya karena mudah dipengaruhi propaganda dan narasi intimidasi kekerasan yang dialami oleh umat Islam dalam konflik Ambon dan Poso hingga membuatnya terlibat dalam aksi Bom Makassar tahun 2003.

Kalau dulu saat konflik Poso-Ambon dan dilibatkan [dalam] Bom Makassar, saya sangat merasa bersalah karena narasi bahwa umat Islam ditindas secara umum, padahal itu hanya sebagian saja. Itu yang membuat saya menyesal karena membuat saya tidak dapat mengontrol kemarahan saya. (AL)

Penyesalan responden AL membuatnya dapat menerima hukuman yang dijalaninya saat ini.

Jadi ini jalan menebus kesalahan saya di masa lalu. (AL)

Responden $\mathrm{H}$ juga menyadari hukuman yang dialami saat ini adalah akibat kesalahannya karena telah terlibat dalam Bom Bali I.

Saya itu sudah mengatakan bahwa dari awal bahwa itu sebuah kesalahan, bukan ketika saya masuk di dalam lapas baru mengakui ini sebuah kesalahan. Biar nggak salah paham, saya mengakui kesalahan itu sebelum Bom Bali dikerjakan. $(\mathrm{H})$

Rasa penyesalan responden $\mathrm{H}$ ini juga dipertegas oleh staf penjara (SO1).

Dia [H] itu tipikal orang yang sensitif, tipikal orang yang mudah hanyut dengan suasana. Jadi waktu pertemuan [dengan] korban [Bom Bali], dengan mereka yang diprakarsai Aliansi Indonesia Damai itu, dia menangis dan minta maaf padahal [dia] bukan pelaku [langsung]-nya. (SO1) 
Pengakuan atas kesalahan dan penyesalan atas tindakan di masa lalu yang ditunjukkan para responden tersebut tidak berujung pada pikiran-pikiran dan perasaan negatif pada diri karena pada saat yang sama para responden juga menyadari bahwa sebagai manusia mereka bisa jatuh dalam kesalahan, sehingga hal yang penting bagi mereka adalah bagaimana menyikapi kesalahan tersebut dengan mendekatkan diri pada Tuhan. Refleksi ini tampak dari ekstrak-ekstrak data berikut.

Ya setelah saya pahami kejadian ini, ketika muncul rasa bersalah saya sering beristighfar [memohon ampunan Tuhan], terus sholat atau membaca Al-Qur'an, berharap semoga kesalahan saya diampuni. (AJ)

Banyak banyak istighfar. Karena Allah itu Maha Pengampun lagi Maha Penyayang kalau kita benar-benar mau bertobat. Kami merasa bersalah kemudian kami terus membenahi diri menjadi lebih baik. (AL)

Responden AJ dan AL merasa bersalah atas apa yang dilakukannya di masa lalu dan berusaha menjadi pribadi yang lebih baik lagi dengan mendekatkan diri dan memohon ampunan kepada Tuhan.

\section{Kemanusiaan Universal}

Ketiga responden penelitian ini juga menunjukkan ciri kemanusiaan universal, yaitu kesadaran atas kelemahan diri sebagai manusia yang membuat mereka dapat menerima kesalahan diri, serta bersikap empati dalam hubungan sosial dan kooperatif dengan petugas selama menjalani hukuman. Para responden penelitian tidak lagi memandang diri secara negatif atau merasa terisolasi karena menyadari semua orang pernah melakukan kesalahan.

Kalau sekarang udah nggak ada penilaian negatif ke diri sendiri nih, ya itu tadi, setiap orang pasti pernah melakukan kesalahan. (AJ)

Karena semua orang pasti pernah melakukan kesalahan. (AL)

Karena semua orang pasti pernah melakukan kesalahan besar. $(\mathrm{H})$

Kesadaran bahwa setiap manusia dapat melakukan kesalahan atau gagal ini memunculkan 
rasa keterhubungan dalam diri para responden dengan orang-orang di sekitarnya. Rasa keterhubungan ini memunculkan sikap empati dan sosial yang melahirkan hubungan sosial yang baik selama dalam penjara. Hal ini terlihat dari pernyataan yang dilaporkan responden $\mathrm{H}$ sebagai berikut:

Ya makin banyak bergaul dengan masyarakat yang heterogen, dulu kan homogen. Sekarang kan macem-macem, jadi lebih tahu tentang kondisi orang lain bagaimana. Ya di dalam penjara juga bisa berbaur, ketawa-tawa, jadi susahnya hilang. Ya harus dibantu ketika mereka [perlu] untuk meringankan beban mereka. (H)

Pernyataan responden $\mathrm{H}$ tersebut diperkuat oleh staf lapas sebagai berikut:

Bagus, justru dia banyak guyonan [bergurau], terus berinteraksi dengan narapidana dengan berbagai suku dan agama itu tidak ada masalah itu. (SO1)

Beliau cukup kooperatif, dan biasanya juga sering main tenis sama pegawai di belakang. Terus dagang makanan, terus kalau sama pegawai juga enak terus kalau sama sesama napi juga enak dia juga punya beberapa teman napi yang dia ajak untuk jualan sayur di dalam lapas. (SO2)

Responden AJ juga melaporkan bahwa ia tidak lagi merasa sendiri dalam menjalani masa hukuman di dalam lapas karena lingkungan sosial di dalam lapas saling mendukung dan membantu.

Di sini kita dan petugas lapas saling menghormati dan saling support. Kita kalau ada apa-apa di bantu, jadi saya rasa kondisi yang demikian itu jadi salah satu faktor membuat kita menjadi lebih baik. (AJ)

Peluang perubahan diri responden menjadi lebih baik telah dimulai sejak pengalaman dalam penangkapan dan penahanan oleh petugas keamanan.

Saya malah melihat kembali, karena saya ditangkap saya melihat keadilan. Karena saya melihat teman-teman BNPT dan petugas itu memiliki perlakuan yang baik, jadi menganggap dan memperlakukan kita seperti manusia biasa, jadi saya bersyukur diberikan jalan seperti ini. Termasuk uluran tangan BNPT sebagai perbandingan, sehingga kita sadar mengenai kesalahan kita. (AL) 
Tindakan manusiawi dari para petugas penjara juga menyumbang kecenderungan ke arah sikap kooperatif dan hubungan sosial yang baik selama dalam penjara.

Jadi penjara seperti ini bukan kayak dulu, jadi tidak ada penyiksaan tapi lebih untuk menyiapkan orang kembali lebih baik. (AJ)

Petugas itu memiliki perlakuan yang baik, jadi menganggap dan memperlakukan kita seperti manusia biasa. Di sini saya baik-baik saja, dengan petugas dengan narapidana tidak ada masalah. Perlakuan pegawai disini sangat bagus jadi seperti keluarga. (AL)

Laporan responden tersebut dikonfirmasi oleh staf lapas.

Sangat bagus, jadi dia interaksi dengan staf lapas dan narapidana lain dengan berbagai suku dan agama tidak ada masalah. (SO1)

Dia sekarang sering sholat jamaah, sholat Jumat, di masjid lapas, dan dia juga dengan narapidana lain mau bertegur sapa. (SO1)

Narapidana terorisme yang masih radikal mengisolasi diri dalam hampir semua kegiatan di lapas, termasuk ibadah sholat. Ketiga responden penelitian ini sudah tidak memiliki ciri demikian.

Laporan ketiga responden penelitian ini terkait kehidupan yang baik selama dalam lapas merupakan respons positif atas pendekatan petugas pendamping khusus narapidana terorisme yang memang menerapkan strategi deradikalisasi dengan pendekatan manusiawi, seperti pada laporan berikut:

Jadi memang pendekatan staf lapas itu juga perlu terutama pendekatan humanisik daripada pendekatan kontra narasi, jadi kalau kontra narasi itu saling adu argumen kalau humanistik itu disentuh hatinya disentuh sisi kemanusiaannya dan juga tidak hanya soal ide radikal saja namun memahami dia sebagai manusia yang memiliki keluarga yang memiliki problem dan keinginan itu juga perlu disentuh. (SO1)

Pendekatan manusiawi terhadap narapidana terorisme ini membuahkan hasil yang baik sebagaimana yang telah tertulis di dalam laporan berikut: 
Ya paling jelas itu kooperatif dalam hal apa, dalam segala program-program di dalam lapas dia aktif, contohnya kegiatan upacara, kegiatan pengajian, kegiatan pihak ketiga. (SO1)

Ya mereka tidak menyendiri, jadi OK OK saja kalau sholat di masjid [bersama narapidana umum lainnya], jadi kalau ada kegiatan di masjid [seperti] ceramah Isra' Mi'raj, Maulid [Peringatan Hari Besar Islam], mereka ya mau datang. (SO2)

\section{Mindfulness}

Laporan ketiga responden penelitian ini menunjukkan adanya ciri mindfulness, yaitu kesadaran atas kenyataan saat ini dan berfokus pada pikiran dan perasaan positif tanpa merepresi emosi negatif. Ketiga responden tidak memikirkan secara berlebihan hal buruk yang pernah dialami akibat dari kesalahannya (overidentifikasi) dan mencoba bersikap optimis.

Responden $\mathrm{H}$ melaporkan rasa sakit hati dan sedih ketika mengingat kejadian penahanan dirinya dan keinginannya untuk segera bebas.

Ya sakit hati, normal lah sebagai manusia. Sedih ada. Susah ada macam-macam lah. Nggak mungkin kalau ditangkap malah senang. $(\mathrm{H})$

Staf penjara melaporkan bahwa tekanan yang dialami responden $\mathrm{H}$ yang paling sering adalah keinginan untuk segera bebas.

Dia hanya berfikir gimana caranya segera pulang. (SO1)

Responden AJ juga melaporkan perasaan diperlakukan secara tidak adil dalam proses pengadilan, sementara responden AL melaporkan pengalaman negatifnya ketika ditahan sebelumnya di lapas lain:

Tapi saya merasa tidak adilnya itu, karena perbedaan pemberlakuan pasal pada kasus narapidana teroris itu, jadi kenapa yang takfiri-takfiri itu cuma sedikit sedangkan kita [saya] seumur hidup. (AJ)

Di [Lapas] Porong ini baik daripada di Lapas Sindur. Peraturan di [Lapas]

Gunung Sindur, jadi [kita] diperlakukan bukan seperti anak bangsa. (AL) 
Kesadaran atas kenyataan bahwa yang terpenting adalah hidup saat ini membuat para responden dapat menerima pengalaman negatifnya dan bersikap optimis. Hal tersebut seperti ungkapan responden AJ berikut yang telah dikonfirmasi oleh staf penjara.

Saya memaklumi dan menerimanya. Ya lambat laun saya menerima kesalahan saya dan terus memperbaiki diri. Positive thinking saja dan kalau ada kegiatan positif ikut aja. (AJ)

Dia ber-positive thinking, dia mengajukan grasi untuk pengurangan masa hukuman. Saya bergaul 13 tahun dengan AJ ini dia itu tipikal orang yang positive thinking. (SO1)

Mengambil sikap positif atas hidup yang dijalaninya sekarang ini telah membuat AJ optimis bahwa suatu saat nanti grasinya akan dikabulkan dan dapat bebas. Begitu juga dengan AL dan $\mathrm{H}$, mereka menerima kenyataan atas hukumannya dan mengambil pelajaran darinya.

Jadi saya tidak adalah masalah, tidak ada rasa sakit [hati] karena saya meyadari bahwa itu kesalahan sesuai hukum negara. Jadi saya bersyukur diberikan jalan sepert ini. Dalam penjara inilah kita bisa banyak introspeksi diri. Jadi persoalan itu dalam perjalanan hidup kita harus bisa mengambil hikmah. (AL)

Saya bersyukur dan tentunya terus introspeksi diri dibarengi dengan terus berbuat baik. $(\mathrm{H})$

Laporan para responden tersebut merefleksikan penerimaan atas hukuman yang dijalaninya dan kemampuannya untuk lebih berfokus pada aspek positif dari kehidupannya di penjara saat ini. Pelajaran penting yang telah diperoleh oleh para responden adalah mereka dapat menggunakan pengalamannya untuk menyadarkan rekan-rekannya yang masih memegang ideologi terorisme.

Saya munculkan [pengalaman terlibat aksi terorisme] ketika bertemu dengan teman-teman yang masih militan untuk menyadarkan mereka. (AL)

Ya bagaimana ya tentunya jangan sampai para muda-mudi yang di luar merasakan penyesalan yang saya rasakan. (AJ)

Saya telah memaafkan diri sendiri, karena setidaknya saya sudah beritahu temanteman [bahwa apa yang ia lakukan di masa lalu adalah keliru]. $(\mathrm{H})$ 
Cara para responden dalam merefleksikan pengalaman hidupnya di dalam penjara secara realistis mengantarkan mereka untuk bersikap positif atas hidupnya saat ini dan memiliki harapan untuk dapat memberikan manfaat dan berkontribusi untuk kebaikan bersama.

\section{DISKUSI}

Hasil penelitian ini menunjukkan bahwa para responden narapidana teroris telah mengalami perubahan diri yang positif, di mana hal ini mengindikasikan bahwa mereka telah memiliki karakteristik belas kasih diri. Karakteristik belas kasih diri yang dimiliki para responden ini tidak terlepas dari pengalaman mereka dalam menjalani program deradikalisasi. Program deradikalisasi yang dijalankan para petugas keamanan dan lapas dalam bentuk perlakuan manusiawi dan dukungan sosial ekonomi kepada para responden memiliki andil dalam membuka hati mereka. Para responden mulai meragukan keyakinannya bahwa para petugas keamanan dan staf penjara adalah musuh yang harus diperangi sesuai dengan pemahaman takfiri yang dulu mereka anut. Pemahaman takfiri adalah pemahaman bahwa individu Muslim yang kafir atau keluar dari Islam pantas untuk dihukum dengan cara dibunuh atau diperangi (Pagar \& Lubis, 2019; Widya, 2020). Beberapa kelompok ekstrim di Indonesia pro-ISIS (Islamic State of Iraq and Syiria), terutama Jamaah Ansharut Daulah (JAD), menggunakan paham takfiri untuk melegitimasi permusuhan dan serangan terhadap aparat pemerintah terutama polisi (Widya, 2020). Banyak penelitian menunjukkan bahwa salah satu faktor yang membuat para teroris terbuka pikirannya adalah belas kasih yang mereka terima dari pihak yang semula dipandang sebagai musuh (Bjorgo, 2009; Garfinkel, 2007; Horgan, 2009). Perlakuan positif dari petugas keamanan dan staf lapas telah membalikkan pola pikir para responden bahwa para musuh ini kejam hingga mendorong mereka untuk mengevaluasi pandangan ideologis yang mereka anut dan keterlibatan mereka dalam jaringan terorisme. Pada akhirnya, responden meragukan keyakinan ideologis mereka, menyadari kesalahan yang telah mereka lakukan di masa lalu, dan menunjukkan penyesalan. Rasa bersalah dan menyesal ini menjadi titik awal dimulainya proses perubahan diri menuju pendirian yang lebih moderat dan menunjukkan belas kasih diri.

Hasil analisis yang telah dilakukan atas hasil penelitian ini menunjukkan bahwa karakteristik ketiga komponen belas kasih diri, yaitu mengasihi diri, kemanusiaan universal, dan mindfulness dapat ditemukan dalam diri ketiga responden narapidana terorisme. Persepsi para responden penelitian atas perlakuan yang baik dan dukungan sosial dari petugas keamanan dan staf 
lapas membantu mereka memandang diri sendiri lebih positif. Pengalaman positif ini telah memperkuat hubungan sosial mereka dengan pihak di luar jaringan kelompok mereka, sekaligus membuat mereka merasa terhubung dengan orang lain sebagai manusia (kemanusiaan universal). Partisipan AJ mengaku mendapat perlakuan positif dari petugas penjara, partisipan AL merasa diperlakukan seperti anggota keluarga sendiri, dan partisipan $\mathrm{H}$ melaporkan memiliki rasa senasib dengan narapidana umum lainnya yang sedang menjalani hukuman dan terpisah dengan keluarga dan dunia luar. Adanya persepsi penerimaan sosial dan perasaan menjadi bagian dari orang-orang di tempatnya berada (self-belonging) merupakan faktor penting dari kemanusiaan universal yang dapat menghindarkan seseorang dari perasaan tereksklusi atau terisolasi akibat rasa bersalah (Wilson dkk., 2020). Hidup bersama dengan para narapidana lain di penjara juga menyadarkan para responden bahwa mereka bukan satu-satunya yang melakukan kesalahan dan menjalani hukuman. Kecenderungan tersebut juga merupakan cerminan dari kemanusiaan universal, individu menyadari bahwa bukan hanya dirinya seorang yang mengalami hal negatif, tetapi juga orang lain (Neff, 2012; Yarnell \& Neff, 2012).

Fuochi dkk. (2018) menemukan bahwa pencapaian kemanusiaan universal pada individu dapat mendorongnya bersikap lebih terbuka dan berempati pada orang lain secara umum dan pada anggota kelompok lain (out-group). Para narapidana terorisme yang menjadi responden penelitian ini telah menunjukkan tindakan yang tepat dalam menjalin hubungan sosial selama di penjara. Mereka bersikap kooperatif dengan petugas, mengikuti program-program lapas, serta berhubungan baik dengan narapidana umum lainnya, termasuk yang berbeda agama dan etnis. Kemampuan menjalin hubungan sosial pada masyarakat yang beragam ini mengindikasikan perubahan cara pandang yang semakin toleran. Sebagaimana dinyatakan oleh Garfinkel (2007), ciri utama pelaku terorisme yang mengalami deradikalisasi adalah perubahan cara pandang yang sebelumnya ekstrem dan radikal menjadi damai dan toleran. Meningkatnya kemanusiaan universal pada diri individu yang terpapar ideologi terorisme dapat mencegah mereka untuk melakukan aksi terorisme dan membuat mereka lebih mendukung upaya damai (DeAngelis, 2009). Perubahan diri yang positif pada ketiga responden narapidana terorisme ini menunjukkan keberhasilan strategi utama deradikalisasi Lapas Porong, yaitu melakukan pendekatan personal humanis dan memberikan dukungan sosial ekonomi. Temuan ini selaras dengan kesimpulan dari Putra dkk. (2018) yang menyatakan bahwa dalam konteks Indonesia, perlakuan yang berfokus pada kebutuhan tersangka, terpidana, dan mantan narapidana kasus terorisme sebagai manusia (humanitarian approach) dan hubungan persahabatan dengan mereka menjadi kunci keberhasilan dan keberlanjutan program 
deradikalisasi. Dalam konteks penjara, Istiqomah (2011) juga melaporkan bahwa pendekatan dan perlakuan yang baik dari petugas terbukti dapat mengubah pemikiran dan sikap radikal narapidana teroris.

Perlakuan yang baik dari petugas yang diiringi dengan pengakuan atas kelemahan diri sebagai manusia biasa yang tidak lepas dari kesalahan (kemanusiaan universal) menjadi landasan penting untuk dapat memaafkan dan menerima diri hingga dapat bersikap ramah, hangat, dan peduli terhadap diri mereka yang tidak sempurna (mengasihi diri). Pengakuan atas kelemahan diri tersebut telah membantu para responden terhindar dari penghakiman atas diri sendiri karena menyadari bahwa mereka tidak sempurna, dapat gagal, dan mengalami hal buruk dalam hidupnya. Kesadaran ini mengarahkan para responden untuk menerima pengalaman negatif sebagai hal yang tak terhindarkan dan yakin akan dapat melaluinya (Neff \& Germer, 2017). Gambaran seperti ini mencerminkan bahwa para responden memiliki kemampuan koping dalam rangka menjaga pandangan positif terhadap diri sendiri. Temuan ini selaras dengan penelitian Allen dan Leary (2010) dan Sirois dkk. (2015) yang menemukan bahwa belas kasih diri berperan penting dalam strategi koping yang efektif dalam mengatasi berbagai masalah psikologis. Jenis strategi koping yang paling terkait adalah restrukturasi kognitif, di mana individu dengan belas kasih diri yang baik akan dapat memikirkan masalah-masalah yang menekan dengan cara yang positif hingga dapat membantunya mengatasi masalah tersebut (Allen \& Leary, 2010). Kemampuan restrukturasi kognitif yang baik dari para responden narapidana terorisme yang dimediasi oleh belas kasih diri ini juga dapat berguna ketika mereka menanggapi respons negatif dari rekan-rekan mereka yang masih radikal. Penelitian Syafiq (2019) menunjukkan bahwa para mantan teroris yang telah sadar dan bertobat seringkali mendapatkan respons negatif dari rekan-rekannya yang masih radikal, seperti tuduhan pengecut, sudah menyerah, dan telah menggadaikan prinsip.

Memaafkan diri sendiri atas kesalahan di masa lalu dan bersikap positif terhadap diri sendiri pada akhirnya membantu para responden mengatasi pikiran dan perasaan negatif yang muncul terkait masa lalu dan dan kehidupan saat ini di lapas. Pikiran dan emosi negatif dipandang sebagai kewajaran ketika kenangan negatif masa lalu muncul dan ketika merenungkan masalah hidup di lapas. Responden $\mathrm{H}$ masih merasa sakit hati apabila mengingat penangkapan dirinya, sedangkan AJ merasa tidak mendapatkan keadilan karena mendapatkan pembedaan pasal dan menerima hukuman yang lebih berat dibandingkan dengan narapidana teroris lainnya. Emosi negatif tersebut dialami responden, tetapi tidak mendominasi kehidupannya. Hal ini menunjukkan ciri mindfulness, yaitu kemampuan menerima kenyataan negatif hidupnya dan mampu berpikir secara terbuka dalam 
merefleksikan penyebab-penyebabnya dengan berfokus pada kehidupan yang saat ini dijalani (Zhang dkk., 2019).

Dalam konteks ini, pikiran dan emosi negatif diterima sebagai risiko yang wajar akibat hidup dalam hukuman yang diakibatkan oleh kesalahan di masa lalu. Alih-alih menanggapi pikiran dan emosi negatif tersebut secara berlebihan, para responden berhasil memilih perspektif yang lebih positif dengan berupaya mencari hikmah di balik pengalaman negatif yang dijalaninya tersebut (mindfulness). Sikap hidup yang diambil ini pada gilirannya dapat membantu para responden dalam mengelola rasa bersalah dan penyesalan atas pengalaman masa lalu dengan memaklumi, serta menerima diri yang lemah hingga terhindar dari kecenderungan untuk mengkritik dan menghukum diri sendiri. Sikap tersebut mendorong responden untuk lebih memahami, bersikap hangat dan peduli, serta mendukung diri sendiri (mengasihi diri). Sikap positif terhadap diri ini selanjutnya membuat para responden menyadari bahwa pikiran dan emosi negatif terkait pengalaman tidak menyenangkan adalah suatu hal yang wajar, tetapi yang terpenting adalah menjalani kehidupan saat ini dan bersikap optimis terhadap apa yang terjadi sekarang (mindfulness).

Menurut Neff dan Germer (2017), mindfulness mengarahkan seseorang untuk berpikir lebih objektif terhadap masalah hidup yang pernah dialaminya dengan berfokus pada kehidupan saat ini. Sikap ini dapat membantu individu dalam mendapatkan pelajaran atau hikmah dari pengalaman yang dijalaninya. Pada para responden penelitian ini, pelajaran yang diambil dari perjalanan hidup mereka adalah merasa memiliki arti ketika berbagi pengalamannya pada orang lain dengan tujuan agar orang lain tidak terjebak pada kesalahan yang sama. Responden AL melaporkan bahwa pengalaman hidup yang ia jalani sebagai mantan pelaku teroris dapat digunakannya untuk menyadarkan rekan-rekannya yang masih menganut pemahaman takfiri. Responden AL juga mengungkapkan rasa syukurnya karena telah tersadar dari paham takfiri yang mendorongnya memilih jalan yang keliru. Hidupnya kini berubah seiring dengan perubahan cara pandangnya terhadap masa lalu. Corner dan Gill (2019) menyatakan bahwa individu yang pernah terlibat dalam terorisme menemui banyak faktor risiko pada level individual, kelompok, maupun sosial selama periode hidupnya yang dapat berdampak negatif secara psikologis. Namun, bukan risiko itu sendiri yang berdampak pada individu, melainkan pada bagaimana individu tersebut mempersepsikan risiko tersebut. Kemampuan ketiga responden ini dalam memikirkan kembali perjalanan hidupnya dan mengevaluasi emosi-emosi negatif yang muncul terkait kesulitan di masa lalu dan saat ini secara terbuka dan realistis telah menghindarkan mereka dari tekanan psikologis. 
Temuan yang menarik dari penelitian ini adalah keberhasilan para responden dalam memaafkan diri atas kesalahan di masa lalu dan penerimaan atas hukuman yang dijalaninya saat ini banyak ditentukan oleh keyakinan religius mereka. Rasa bersalah dan penyesalan dapat berdampak negatif secara psikologis jika tidak dikelola dengan tepat. Para responden memiliki modal yang baik dalam sikap religius mereka. Hasil penelitian ini menunjukkan bahwa para responden memperoleh ketenangan dengan berusaha mendekatkan diri pada Tuhan. Mereka meyakini bahwa Tuhan akan mengampuni dosa-dosa hambaNya yang telah bertobat. Sikap religius ini telah membantu para responden untuk menerima hidupnya saat ini. Responden $\mathrm{H}$, misalnya, percaya bahwa perjalanan hidupnya sudah merupakan takdir Tuhan yang membuatnya berusaha terus memperbaiki diri dengan cara mendekatkan diri pada Tuhan. Pengalaman spiritual para responden ini menjadi landasan penting dari pertumbuhan belas kasih diri mereka. Temuan ini selaras dengan hasil-hasil penelitian sebelumnya yang melaporkan bahwa belas kasih diri berkaitan erat dengan pengalaman spiritual pada berbagai sampel penelitian (Hidayati dkk., 2019; Mathad, dkk., 2019; Thomas dkk., 2019). Belas kasih diri memfasilitasi perasaan positif, optimis, dan rasa syukur yang membuat individu menunjukkan penerimaan atas ketidaksempurnaan hidup yang dijalaninya (Neff \& Germer, 2017). Oleh karena itu, memiliki belas kasih diri membuat para responden tersebut lebih berpikir positif dan optimis atas kehidupannya saat ini di penjara dan memandang bahwa upaya untuk terus memperbaiki diri agar menjadi pribadi yang lebih baik adalah hal yang terpenting.

\section{SIMPULAN DAN SARAN}

\section{Simpulan}

Penelitian ini menyimpulkan bahwa para responden penelitian menunjukkan ekspresi perilaku yang konsisten dengan karakteristik belas kasih diri sesuai dengan teori Neff (2003). Belas kasih diri para responden penelitian tidak dapat dilepaskan dari keikutsertaan mereka dalam program deradikalisasi. Pendekatan manusiawi aparat keamanan dan petugas lapas sebagai implementasi program deradikalisasi menjadi faktor penting yang memfasilitasi kemunculan belas kasih diri tersebut. Hasil penelitian ini mengkonfirmasi beberapa hasil penelitian sebelumnya yang menemukan bahwa belas kasih dan dukungan sosial yang diterima oleh para penganut dan pelaku ekstremisme kekerasan dari pihak yang sebelumnya dipandang musuh dapat melahirkan belas kasih diri pada diri mereka. Belas kasih diri ini selanjutnya dapat memfasilitasi mereka untuk berubah 
menjadi lebih moderat dan toleran. Berdasarkan temuan ini, dapat disimpulkan bahwa belas kasih diri dapat digunakan sebagai salah satu indikator psikologis untuk mengevaluasi keberhasilan para narapidana terorisme dalam menjalani program deradikalisasi.

\section{Saran Teoretis}

Penelitian ini mengkaji belas kasih diri dengan merujuk pada teori belas kasih diri dari Neff (2013). Oleh karena itu, hasil penelitian ini lebih terbatas pada memberi gambaran belas kasih diri pada narapidana terorisme sesuai dengan teori tersebut. Penelitian selanjutnya pada responden sejenis disarankan untuk lebih menggali konsep belas kasih diri yang didasarkan pada konteks sosial, budaya, dan agama mereka. Penelitian semacam ini akan dapat mengembangkan dan memperkaya konsep belas kasih diri yang lebih mencerminkan karakteristik masyarakat dari mana para responden berasal.

Selain itu, penelitian ini memiliki jumlah responden yang masih sedikit dan hanya mengandalkan wawancara dalam mengumpulkan data. Penelitian selanjutnya disarankan untuk menambahkan teknik pengumpulan data lain, misalnya focus group discussion (FGD), dan merekrut lebih banyak responden narapidana terorisme dari berbagai lapas untuk dapat memperdalam data terkait dimensi psikologis dari program deradikalisasi yang dijalani. Memilih beberapa lapas yang berbeda berguna untuk membuat perbandingan kebijakan program deradikalisasi pada tiap lapas dan implikasinya pada dimensi psikologis yang diteliti. Penelitian selanjutnya yang bersifat terapan, misalnya menggunakan intervensi belas kasih diri pada narapidana terorisme, juga penting dilakukan untuk melihat perubahan diri mereka ke arah sikap moderat terutama pada aspek empati dan keterbukaan pada perbedaan.

\section{Saran Praktis}

Ada dua saran praktis yang ingin peneliti sampaikan berdasarkan hasil penelitian ini. Pertama, pendekatan interpersonal dan humanis petugas Lapas Kelas 1 Surabaya terhadap narapidana terorisme merupakan faktor penting yang menunjang kesuksesan program deradikalisasi bagi para narapidana terorisme. Cara tersebut dapat menjadi model dalam hubungan petugas lapas dengan narapidana terorisme di lapas yang lain. Kedua, perlu dilakukan berbagai kegiatan dalam rangka edukasi publik untuk menurunkan stigma masyarakat terhadap mantan narapidana terorisme agar mereka yang sudah sukses menjalani program deradikalisasi di lapas dapat berintegrasi kembali dengan masyarakat ketika mereka telah bebas. Strategi yang dapat dilakukan di antaranya 
dengan melibatkan pimpinan informal maupun formal di tempat tinggal mantan narapidana terorisme untuk secara reguler mengikutsertakan mantan narapidana tersebut dalam kegiatan warga, misalnya rapat Rukun Tetangga (RT), kerja bakti, atau kegiatan sosial lainnya. Pada tingkat yang lebih luas, para mantan narapidana terorisme dapat dilibatkan dalam kegiatan sosial dan ekonomi bersama lembaga pemerintah maupun non-pemerintah untuk meningkatkan kesejahteraan mereka maupun masyarakat umum. Cerita kesuksesan para mantan narapidana terorisme dalam reintegrasi sosial melalui berbagai kegiatan sosial ekonomi tersebut selanjutnya dapat dikemas menjadi berita yang disebarkan melalui berbagai media secara nasional.

\section{UCAPAN TERIMA KASIH}

Terima kasih kepada Staf Lapas Kelas I Surabaya Pendamping Napi Terorisme yang telah membantu perekrutan responden penelitian ini.

\section{ASPEK ETIK STUDI}

\section{Pernyataan Etik}

Seluruh prosedur yang dilakukan pada studi ini telah sesuai dengan Deklarasi Helsinki tahun 1964 dan segala adendumnya atau dengan standar etika yang relevan. Persetujuan etik atas penelitian ini tidak menjadi syarat dari lembaga asal peneliti. Namun, sebelum penelitian dilaksanakan, proposal penelitian ini telah dievaluasi dan diberi persetujuan oleh tim panel dosen di lembaga peneliti dan telah mendapat surat izin penelitian dari Kemenkumham RI Wilayah Jawa Timur (No: W.15-UM.01.01-3597). Pernyataan kesediaan berpartisipasi dari seluruh partisipan telah diperoleh dengan bukti dokumen lembar persetujuan yang telah ditandatangani oleh mereka.

\section{Konflik Kepentingan}

Penulis menyatakan tidak ada konflik kepentingan dalam pelaksanaan penelitian dan penulisan artikel berdasarkan penelitian ini.

\section{Ketersediaan Data}

Data bersifat anonim yang digunakan dalam studi ini dapat diakses pihak lain untuk kepentingan verifikasi atau kepentingan ilmiah lain dengan menghubungi penulis korespondensi melalui surel.

\section{REFERENSI}

Allen, A. B., \& Leary, M. R. (2010). Self-compassion, stress, and coping. Social and Personality Psychology Compass, 4(2), 107-118. https://doi.org/10.1111/j.1751-9004.2009.00246.x 
Badan Pembinaan Hukum Nasional. (2020, Juli 17). Turun ke Lapas, BPHN tangkal penyebaran paham radikalisme di kalangan napi. https://lsc.bphn.go.id/news?nid=1141\&id_page=108

Barnard, L. K., \& Curry, J. F. (2011). Self-compassion: Conceptualizations, correlates, \& interventions. Review of General Psychology, 15(4), 289303. https://doi.org/10.1037/a0025754

Bjorgo, T. (2009). Processes of disengagement from violent groups of the extreme right. Dalam T. Bjorgo \& J. Horgan (Eds.), Leaving terrorism behind: Individual and collective disengagement (hlm. 30-48). Routledge.

Braun, V., \& Clarke, V. (2006). Using thematic analysis in psychology. Qualitative Research in Psychology, 3(2),77-101. https://doi.org/10.1191/1478088706qp063oa

Britannica, T. Editors of Encyclopaedia. (2020, Oktober 4). 2002 Bali Bombings. Encyclopedia Britannica. https://www.britannica.com/event/2002-Bali-Bombings

Cherney, A. (2016). Designing and implementing programmes to tackle radicalization and violent extremism: Lessons from criminology. Dynamics of Asymmetric Conflict, 9(1-3), 82-94. https://doi.org/10.1080/17467586.2016.1267865

Cherney, A. (2018). Evaluating interventions to disengage extremist offenders: A study of the proactive integrated support model (PRISM). Behavioral Sciences of Terrorism and Political Aggression, 12(1), 17-36. https://doi.org/10.1080/19434472.2018.1495661

Corner, E., \& Gill, P. (2020). Psychological distress, terrorist involvement and disengagement from terrorism: A sequence analysis approach. Journal of Quantitative Criminology, 36, 499526. https://doi.org/10.1007/s10940-019-09420-1

Creswell, J. W. (2014). Penelitian kualitatif \& desain riset: Memilih di antara lima pendekatan. Pustaka Pelajar.

DeAngelis, T. (2009). Understanding terrorism. Monitor on Psychology, 40(10), Article 60. https://www.apa.org/monitor/2009/11/terrorism

Direktorat Jendral Pemasyarakatan Kemenkumham RI. (2015, Mei 20). Umar patek janji setia cintai NKRI. http://www.ditjenpas.go.id/umar-patek-janji-setia-cintai-nkri

Dreisoerner, A., Junker, N. M., \& van Dick, R. (2020). The relationship among the components of self-compassion: A pilot study using a compassionate writing intervention to enhance selfkindness, common humanity, and mindfulness. Journal of Happiness Studies, 22, 21-47. https://doi.org/10.1007/s10902-019-00217-4 
Fuochi, G., Veneziani, C. A., \& Voci, A. (2018). Exploring the social side of self-compassion: Relations with empathy and outgroup attitudes. European Journal of Social Psychology, 48(6), 769-783. https://doi.org/10.1002/ejsp.2378

Garfinkel, R. (2007). Personal transformations: Moving from violence to peace. United States Institute of Peace. https://www.usip.org/publications/2007/04/personal-transformationsmoving-violence-peace

Gómez, M. R. D., Pino , J. D., \& Pino, R. D. (2020). Self-compassion and predictors of criminal conduct in adolescent offenders. Journal of Aggression Maltreatment \& Trauma, 29(8), 1020-1033. https://doi.org/10.1080/10926771.2019.1697778

Hettiarachchi, M. (2018). Rehabilitation to deradicalise detainees and inmates: A counter-terrorism strategy. Journal of Policing, Intelligence and Counter Terrorism, 13(2), 267-283. https://doi.org/10.1080/18335330.2018.1476774

Hidayati, F., Istiqomah, A. N., \& Scarvanovi, B. W. (2019). Spirituals function in health on medical students: A perspective from self-compassion. KnE Life Sciences, 4(12), 21-29. https://doi.org/10.18502/kls.v4i12.4153

Horgan, J. (2009). Individual disengagement: A psychological analysis. Dalam T. Bjorgo \& J. Horgan (Eds.), Leaving terrorism behind: Individual and collective disengagement (hlm. 17-29). Routledge.

Horgan, J., \& Altier, M. B. (2012). The future of terrorist de-radicalization program. Georgetown Journal of International Affairs, 13(2), 83-90. https://www.jstor.org/stable/43134238

Horgan, J., \& Braddock, K. (2010). Rehabilitating the terrorists?: Challenges in assessing the effectiveness of de-radicalization programs. Terrorism and Political Violence, 22(2), 267291. http://dx.doi.org/10.1080/09546551003594748

Hwang, J. C. (2018). Why terrorist quit: The disengagement of Indonesian jihadist. Cornell University Press.

Institute of Economics and Peace (IEP). (2020). Global terrorism index 2020: Measuring the impact of terrorism. https://www.visionofhumanity.org/wp-content/uploads/2020/11/GTI2020-web-1.pdf

Institute for Policy Analysis of Conflict (IPAC). (2016). Update on Indonesian Pro-ISIS prisoners and deradicalisation efforts. http://www.understandingconflict.org/en/conflict/read/57/Update-on-Indonesian-Pro-ISISPrisoners-and-Deradicalisation-Efforts 
Istiqomah, M. (2011, Desember 5-7). Deradicalization program in Indonesia prisons: Reformation on the correction institution [Paper presentation]. 1st Australian Counter Terrorism Conference, Edith Cowan University, Perth Western Australia. https://doi.org/10.4225/75/57a4200e2b5a3

Kundnani, A., \& Hayes, B. (2018). The globalisation of Countering Violent Extremism policies: Undermining human rights, instrumentalising civil society. The Transnational Institute (TNI). https://www.tni.org/files/publication-downloads/cve_web.pdf

Mareta, J. (2018). Rehabilitasi dalam upaya deradikalisasi narapidana terorisme. Jurnal MasalahMasalah Hukum, 37(4), 338-356. https://ejournal.undip.ac.id/index.php/mmh/article/viewFile/18002/14360.

Mathad, M. D., Rajesh, S. K., \& Pradhan, B. (2019). Spiritual well-being and its relationship with mindfulness, self-compassion and satisfaction with life in baccalaureate nursing students: A correlation study. Journal of Religion and Health, 58, 554-565. https://doi.org/10.1007/s10943-017-0532-8

Morley, R. H. (2015). Violent criminality and self-compassion. Aggression and Violent Behavior, 24, 226-240. http://dx.doi.org/10.1016/j.avb.2015.05.017

Morley, R. H. (2018). The impact of mindfulness meditation and self-compassion on criminal impulsivity in a prisoner sample. Journal of Police and Criminal Psychology, 33, 118-122. https://doi.org/10.1007/s11896-017-9239-8

Morley, R. M., Terranova, V. A., Cunningham, S. A., \& Kraft, G. (2016). Self-compassion and predictors of criminality. Journal of Aggression, Maltreatment \& Trauma, 25(5), 503-517. https://doi.org/10.1080/10926771.2015.1107170

Neff, K. D. (2003). Self-compassion: An alternative conceptualization of a healthy attitude toward oneself. Self and Identity, 2(2), 85-101. https://doi.org/10.1080/15298860309032

Neff, K. D. (2012). The science of self-compassion. Dalam C. Germer \& R. Siegel (Eds.), Compassion and wisdom in psychotherapy (hlm. 79-92). Guildford Press.

Neff, K. D. \& Germer, C. (2017). Self-compassion and psychological wellbeing. Dalam J. Doty (Ed.), Oxford handbook of compassion science (hlm. 371-385). Oxford University Press.

Pagar, \& Lubis, S. A. (2019). Faham takfiri menurut ulama sunni Indonesia pasca kelesuan ISIS di Suriah (Aspek-aspek pengkafiran dan militansi perjuangan). Journal Analytica Islamica, 21(2), 156-170. http://jurnal.uinsu.ac.id/index.php/analytica/article/view/7079 
Putra, I. E., Danamasi, D. O., Rufaedah, A., Arimbi, R. S., \& Priyanto, S. (2018). Tackling Islamic terrorism and radicalism in Indonesia by increasing the sense of humanity and friendship. Dalam B. L. Cook (Ed.), Handbook of research on examining global peacemaking in the digital age (hlm. 94-114). IGI Global.

Putra, I. E., \& Sukabdi, Z. A. (2014). Can Islamic fundamentalism relate to nonviolent support? The role of conditions in moderating the effect of Islamic fundamentalism on supporting acts of terrorism. Journal Peace and Conflict, 20(4). 583-589. https://doi.org/10.1037/pac0000060

Schmid, A. P. (2013). Radicalisation, de-radicalisation, counter-radicalisation: A conceptual discussion and literature review. The International Centre for Counter-Terrorism - The Hague, 4(2), 1-105. http://dx.doi.org/10.19165/2013.1.02

Sirois, F. M., Molnar, D. S., \& Hirsch, J. K. (2015). Self-compassion, stress, and coping in the context of chronic illness. Self and Identity, 14(3), 334-347. https://doi.org/10.1080/15298868.2014.996249

Sukabdi, Z. A. (2015). Terrorism in Indonesia: A review on rehabilitation and deradicalization. Journal of Terrorism Research, 6(2), 36-56. https://doi.org/10.15664/jtr.1154

Syafiq, M. (2019). Deradicalisation and disengagement from terrorism and threat to identity: An analysis of former jihadist prisoners' accounts. Psychology and Developing Societies, 31(2), 227-251. https://doi.org/10.1177/0971333619863169

Thomas, C. L., Cuceu, M., Tak, H. J., Nikolic, M., Jain, S., Christou, T., \& Yoon, J. D. (2019). Predictors of empathic compassion: Do spirituality, religion, and calling matter?. Southern Medical Journal, 112(6), 320-324. https://doi.org/10.14423/SMJ.0000000000000983

Widya, B. (2020). Pemahaman takfiri terhadap kelompok teror di Indonesia studi komparasi Jamaah Islamiyah dan Jamaah Ansharut Daulah. Jurnal Studi Diplomasi Dan Keamanan, 12(2), 76-93. https://doi.org/10.31315/jsdk.v12i2.3525.g2668

Wilson, J. M., Weiss, A., \& Shook, N. J. (2020). Mindfulness, self-compassion, and savoring: Factors that explain the relation between perceived social support and well-being. $\begin{array}{llll}\text { Personality and } \quad \text { Individual } & \text { Differences, } & 152, & 1-9 .\end{array}$ https://doi.org/10.1016/j.paid.2019.109568

Yang, Y., Guo, Z., Wu, J., \& Kou, Y. (2020). Self-compassion relates to reduced unethical behavior through lower moral disengagement. Mindfulness, 11, 1424-1432. https://doi.org/10.1007/s12671-020-01354-1 
Yanuarti, U. K., \& Sularto, R. B. (2014). Counter-terorism bagi pelaku tindak pidana terorisme sebagai upaya penanggulangan kejahatan terorisme di Indonesia. Law Reform, 10(1), 8498. https://doi.org/10.14710/lr.v10i1.12459

Yarnell, L. M., \& Neff, K. D. (2012). Self-compassion, interpersonal conflict resolutions, and wellbeing. Self and Identity, 12(2), 146-159. https://doi.org/10.1080/15298868.2011.649545

Yin, R. K. (2014). Studi kasus: Desain \& metode. Raja Grafindo Persada.

Zhang, J. W., Chen, S., \& Tomova Shakur, T. K. (2020). From me to you: Self-compassion predicts acceptance of own and others' imperfections. Personality and Social Psychology Bulletin, 46(2), 228-242. https://doi.org/10.1177/0146167219853846 